\title{
UNDOCUMENTED MIGRANT WOMEN IN EUROPE: A HUMAN RIGHTS PERSPECTIVE FROM PUBLIC INTERNATIONAL LAW
}

\author{
Dorothy Estrada-Tanck
}

\begin{abstract}
Summary: Undocumented migrant women in Europe - many potential refugees - face cumulative forms of discrimination and heightened vulnerability, including the risk of suffering violence. This article explores the implications of viewing their situation through the lens of public international law, particularly international human rights law, as an indispensable companion to European human rights law. It argues for the incorporation of the UN normative and interpretative framework on the human rights of undocumented migrants into European legal and judicial analysis. The UN legal architecture constitutes an essential component to better understand the transnational phenomenon of migration in an interrelated world with combined and overlapping legal regimes. These instruments crafted within the realm of public international law may also play a key orienting role for the ECtHR to adequately uphold the rights of (female) undocumented migrants and for States to attend more justly to the dire conditions of many undocumented migrant women and girls in Europe.
\end{abstract}

\section{Introduction}

This article critically maps the relationship between UN human rights instruments and European human rights law concerning the rights of undocumented migrant women, it spells out the normative and interpretative implications of this link, and it explores its conceptual and practical value in the context of the aggravated vulnerability and violations experienced by them.

In section 2 , it explores the relevant normative framework and the empirical reality affecting female undocumented migrants. First, it analyses the international legal framework on the human rights of undocumented migrants and other non-citizens such as asylum seekers and refugees, at the UN level and that of the European system of human rights, focusing particularly on the conditions of female undocumented migrants. Secondly, it reviews the conditions of undocumented migrant

PhD in Law, European University Institute. Professor of Public International Law in IE Law School, Madrid. 
women and girls in Europe, highlighting their situation of aggravated vulnerability.

As a result of contrasting the normative and the factual spheres affecting female undocumented migrants, in section 3 the paper explores the reactions produced by international and European human rights bodies, including judicial responses by the European Court of Human Rights.

Finally, in section 4 , the paper provides some conclusions that reflect upon the potentials and limitations of the current legal framework in upholding key values at the heart of European human rights instruments and democratic values - particularly relevant in light of the current humanitarian crisis of refugees in Europe.

\section{Undocumented female migrants: normative and empirical approaches}

As a necessary starting point, this section addresses the general definition of 'undocumented migrant', as well as its differences from the legal figures of 'asylum seeker' and 'refugee' to clarify the specific normative implications in each type of situation. Then it explores the international legal framework applicable to the condition of undocumented migrants, particularly women, from the perspectives both of the UN and the European systems of human rights. Finally, it addresses the main differentiated risks and types of violence faced by undocumented migrant girls and women in Europe, as well as the vulnerabilities experienced more specifically by female undocumented migrant domestic workers.

\subsection{Who is an undocumented migrant?}

According to current data, the International Organization for Migration (IOM) estimated in 2012 that that there were 214 million international migrants worldwide, that is, persons living and/or working in a country other than that of their birth or citizenship. ${ }^{1}$ The total number of international migrants increased over a period of 10 years from an estimated 150 million in 2000 to 214 million in 2010; in other words, 3.1\% of the world's population, or one in every 33 persons in the world today, are migrants. If considered in the aggregate, migrants would constitute the fifth most populous country in the world. ${ }^{2}$ However, it is hard to provide

\footnotetext{
1 International Organization for Migration, World Migration Report 2011: Communicating Effectively About Migration (International Organization for Migration 2011) 49.

2 See the International Organization for Migration (IOM) <www.iom.sk/en/about-migration/migration-in-the-world>; and <www.unfpa.org/migration> both accessed 2 December 2016.
} 
an exact number of undocumented migrants, precisely because of their irregular legal status.

While the legal framework presents a definition of 'migrant worker' applicable both to documented and undocumented migrant workers - it does not offer a more general definition of the migrant person, particularly for those migrants that are in an irregular situation regarding their entry to or residence in a given State. There is one notable exception, which is taken up in Advisory Opinion 18/03 of the Inter-American Court of Human Rights of $2003,{ }^{3}$ which defines 'migrant' as 'any person who emigrates' - 'leaves a State in order to transfer to another and establish himself there' - or 'immigrates' - 'enters another State in order to reside there'.

Specifically with the words 'undocumented migrant', this paper understands those persons without a residence permit authorising them to regularly stay or work in their country of destination. They may have been unsuccessful in the asylum procedure, have overstayed their visa or have entered the relevant country irregularly. The routes to becoming an undocumented migrant are complex, and at times the result of arbitrary policies and procedures over which the migrant has little or no control.

Regarding some of the receiving regions and countries in the developed world, ${ }^{4}$ civil society actors addressing this field in Europe, for example, estimate that the majority of undocumented migrants enter Europe legally, but after a period of time experience difficulties and find themselves without the relevant permit for residence or employment. It has been stressed that irregularity is caused by an administrative infringement and not a criminal offence. It is often a process fuelled by exploitation, redundancy, misinformation and administrative delays'. ${ }^{5}$ Civil society in the US has also highlighted immigrant rights as a means to test the condition of human rights in society at large, by signalling that: '[W] hen the government has the power to deny legal rights and due process to one vulnerable group, everyone's rights are at risk'. ${ }^{6}$

\footnotetext{
3 Inter-American Court of Human Rights, 'Juridical Condition and Rights of Undocumented Migrants', Advisory Opinion OC-18/03 (AO 18/03) requested by the United Mexican States, 17 September 2003, para 69(a) to (e).

4 Possibly in contrast to popular perception, the receiving countries with the highest number of migrants, in terms of the percentage of their total population, are not in the Global North. Countries with a high percentage of migrants include Qatar (87\%), United Arab Emirates (70\%), Jordan $(46 \%)$, Singapore (41\%), and Saudi Arabia (28\%); see <www.iom.int/world-migration> accessed 2 December 2016.

5 Platform for International Cooperation on Undocumented Migrants (PICUM) <www. picum.org/en/our-work/undocumented-migrants/> accessed 2 December 2016; PICUM leads a 'network of concerned individuals and organizations committed to ensuring real sustainable change for undocumented migrants by informing and influencing policy makers'.

6 See American Civil Liberties Union, 'ACLU's “Immigrants" Rights Project' <www.aclu. org/issues/immigrants-rights> accessed on 2 December 2016.
} 
Returning to legal definitions in the realm of UN instruments, the International Convention on the Protection of the Rights of All Migrant Workers and Members of their Families (CRMW), ${ }^{7}$ in article 2.1, offers a definition of 'migrant worker' as 'a person who is to be engaged, is engaged or has been engaged in a remunerated activity in a State of which he or she is not a national'. In article 5, the CRMW clarifies that migrant workers and members of their families:

(a) Are considered as documented or in a regular situation if they are authorised to enter, to stay and to engage in a remunerated activity in the State of employment pursuant to the law of that State and to international agreements to which that State is a party; and

(b) Are considered as non-documented or in an irregular situation if they do not comply with the conditions provided for in subparagraph (a) of the present article.

With this legal definition as a background, one may also point out that people do not move from their place of origin or residence following neat and clear-cut legal taxonomies, but rather that in social reality migratory flows are mixed and complex. Because of this, let us turn to the main differences between undocumented migrants and other categories of non-citizens under public international law.

\subsubsection{Undocumented migrants, asylum seekers, and refugees}

Undocumented migrants are usually termed 'economic migrants' escaping poverty and deprivation, differentiating them from refugees escaping persecution and armed conflict. Let us bear in mind, though, that people seeking 'asylum' or 'refuge' are requesting or are in need of precisely the proper 'documents' where the status of 'refugee' is recognised. As such, many undocumented migrants - insofar as their situation is dependent on the granting (or not) of official State 'documents' - are asylum seekers or potential refugees expectant of recognition or regularisation of their condition. That being said, the specific legal figure of 'refugee', distinct from that of 'undocumented migrant' or other 'non-citizens', merits attention. The current humanitarian crisis experienced by persons fleeing mainly from Syria, but also from Libya, Iraq and Afghanistan, gives an additional reason to consider the particular vulnerability of refugees.

\footnotetext{
7 International Convention on the Protection of the Rights of All Migrant Workers and Members of Their Families UNGA Res 45/158, annex, 45 UN GAOR Supp No 49, 262, UN Doc A/45/49 (1990) (adopted 18 December 1990, entered into force 1 July 2003) 2220 UNTS 3.
} 
The two basic instruments of international refugee law, the 1951 Convention on the Status of Refugees and its 1967 Protocol, define a refugee as a person who is outside his or her country of nationality or habitual residence; has a well-founded fear of being persecuted because of his or her race, religion, nationality, membership of a particular social group or political opinion; and is unable or unwilling to avail him or herself of the protection of that country, or to return there, for fear of persecution. ${ }^{8}$ Their situation is often so dangerous and intolerable that they cross national borders to seek safety in nearby countries, and thus become internationally recognised as 'refugees' with access to assistance from States, the UN High Commissioner for Refugees (UNHCR), and other organisations. People who meet the refugee definition deserve State protection (generically called 'asylum' - hence the term 'asylum seekers') and are entitled to the rights and are bound by the duties contained in the 1951 Convention. ${ }^{9}$

Let us also recall that article 33 of the Refugee Convention sets forth an obligation of protection of refugees by prohibiting States from expelling or returning them when they face a risk to their life or freedom ('refouler'). In a complementary manner, article 3 ECHR (1950), article 3 of the UN Convention Against Torture, and article 7 of the International Covenant on Civil and Political Rights (ICCPR) all include an obligation of protection of any person confronting a risk of torture or inhuman or degrading treatment, an obligation that is not subject to exception and constitutes ius cogens. The expansion of the status of 'refugee' under this definition grounds the entitlement of the person to 'subsidiary protection' from the State. Thus, both under refugee law and human rights law, the risk of persecution and risk of torture or ill-treatment have become wellestablished conditions for triggering an obligation of protection from the State under the principle of non-refoulement. ${ }^{10}$ A recent interpretation of

\footnotetext{
8 See art $1 \mathrm{~A}(2)$ of the Convention relating to the Status of Refugees, adopted on 28 July 1951 by the UN Conference of Plenipotentiaries on the Status of Refugees and Stateless Persons convened under General Assembly Resolution 429 (V), which entered into force on 22 April 1954. See also the Protocol on the Status of Refugees, approved in New York on 31 January 1967 and which entered into force on 4 October 1967, in conformity with Article VIII. The Protocol opens up the definition of refugee of the 1951 Convention to universal application, by suppressing the reliance on occurrences having happened before 1 January 1951 and by eliminating any geographic limitation in the applicability of the 1951 Convention (given the 1951 definition is confined only to Europe).

9 For the recognition of the status of refugee as a declaratory (and not constitutive) act, as well as on the institution of asylum as predating the international legal regime for refugees, see Maria-Teresa Gil-Bazo, 'Refugee Status, Subsidiary Protection, and the Right to be Granted Asylum under EC Law' (November 2006) Research Paper No 136, Refugee Studies Centre, Oxford University, UK-UNHCR Policy Development and Evaluation Service.

10 See the analysis by Aoife Duffy, 'Expulsion to Face Torture? Non-refoulement in International Law' (2008) 20(3) International Journal of Refugee Law, 373. See also American Convention on Human Rights, art 22, para 8; and African Charter on Human and People's Rights, art 5.
} 
the UN Convention on the Elimination of Discrimination Against Women (CEDAW), provided by the UN CEDAW Committee in 2014, suggests a further enhancement of the applicability of the non-refoulement obligation to cover cases of 'serious forms of discrimination against women, including gender-based violence'. ${ }^{11}$

Let us now turn to analyse how the global and European legal regimes have developed and interpreted human rights standards affecting undocumented migrants, particularly female migrants, and the implications of the relationship between both normative frameworks.

\subsection{The normative legal framework for the human rights of migrants}

This section explores the international legal regime concerning undocumented migrants in general, at the levels of the UN and European systems of human rights. This sets the stage for focusing more specifically on the situation of undocumented migrant women and girls and the response by human rights actors towards their condition of structural vulnerability.

\subsubsection{The UN System}

Based on the principles of equality and non-discrimination, the UN legal framework has consistently reaffirmed the human rights of all migrants and the prohibition of discrimination founded on national or social origin. ${ }^{12}$ Only one of the nine core treaties in the whole UN human rights treaty system refers to migrants - specifically to migrant workers and their families. The 1990 International Convention on the Protection of the Rights of All Migrant Workers and Members of their Families (CRMW), which entered into force in 2003, refers as its name suggests to the rights of all migrant workers, ie both documented and undocumented migrant workers, and members of their families. ${ }^{13}$ Part IV of the CRMW also provides for additional rights specifically for documented migrant workers. The CRMW constitutes the only human rights treaty with the

\footnotetext{
11 See CEDAW, 'General recommendation no 32 on the gender-related dimensions of refugee status, asylum, nationality and statelessness of women' (CEDAW/C/GC/32, 14 November 2014) para 22 .

12 See the general basis in arts 1(3) and 55 of the UN Charter and specific mention in art 2 of the Universal Declaration of Human Rights (adopted 10 December 1948) UNGA Res 217 A (III), UN Doc A/810, 71 (1948).

13 The Convention was drafted based on two prior instruments, the International Labour Organization (ILO) Migration for Employment Convention of 1949 (No 97) and the ILO Migrant Workers (Supplementary Provisions) Convention of 1975 (No 143), which together constitute what has been called the 'international charter on migration'; see P Taran, 'Clashing Worlds: Imperative for a Rights-based Approach to Labour Migration in the Age of Globalization' in V Chetail (ed), Mondialisation, migration et droits de l'homme: le droit international en question/ Globalization, Migration and Human Rights: International Law under Review (vol 2, Bruylant 2007) 403, 421.
} 
universal aspiration that places existing human rights standards in the specific context of migration.

Within the member states of the CRMW, one may find mostly countries of origin but also some countries of transit and/or hosting of large numbers of migrants, such as Mexico and Turkey. Among ratifying States, there are countries from almost all regions of the world, except for the EU. However, 11 Member States of the EU have ratified one or both of the Conventions of the International Labour Organization (ILO) which served as a basis for the CRMW (nos 97 and 143), and two non-EU European States, Turkey and Albania, are parties to the CRMW; this is an interesting fact if one considers Turkey is at the time of writing the host country of the majority of migrants deriving from the armed conflict in Syria. While most of these persons are refugees, others will foreseeably find themselves in the position of undocumented migrants and/or will possibly deserve overlapping protection from different legal instruments, including the CRMW.

Other human rights treaty bodies have also consistently reaffirmed the applicability of all human rights - civil, political, economic, social and cultural - to migrant persons and the prohibition of discrimination based on national origin or immigration status. ${ }^{14}$

For the effects of expulsion of non-nationals from a State's territory, and the obligations of European States in this context, let us recall article 13 of the International Covenant on Civil and Political Rights (ICCPR, to which most European and EU States are Parties). Under the ICCPR, migrants enjoy specific guarantees of due process and review against expulsion measures, including the right to defence and the right to legal representation. Article 13 ICCPR, though, only includes explicitly 'lawful aliens':

14 See art 27 of the International Covenant on Civil and Political Rights, UNGA Res 2200A (XXI), 21 UN GAOR Supp No 16, 52, UN Doc A/6316 (adopted 16 December 1966, entered into force 23 March 1976) 999 UNTS 171 (ICCPR) which refers to ethnic, religious and linguistic minorities; art 30 of the Convention on the Rights of the Child, UNGA Res 44/25, UN GAOR Supp No 49, 167, UN Doc A/44/49 (1989) (adopted 20 November 1989, entered into force 2 September 1990) and art 5 of the Vienna Declaration and Programme of Action, adopted by the World Conference on Human Rights, Vienna, 25 June 1993); Declaration on the Human Rights of Individuals Who Are Not Nationals of the Country in which They Live, UNGA Res 40/144 (13 December 1985) UN Doc A/RES/40/144; UNHRC, 'ICCPR General Comment 15: The Position of Aliens under the Covenant' (11 April 1986); UNHRC, 'ICCPR General Comment 23: The Rights of Minorities (art 27) (1994)', indicating that the rights of art 27 ICCPR also apply to migrant workers; Committee on the Elimination of Racial Discrimination General Recommendation No 30, Discrimination against Non-Citizens (2004); Committee on the Rights of the Child General Comment No 6, Treatment of Unaccompanied and Separated Children Outside Their Country of Origin (2005); and Committee on the Elimination of Discrimination Against Women General Recommendation No 26 on Women Migrant Workers (2008). 
An alien lawfully in the territory of a State Party to the present Covenant may be expelled therefrom only in pursuance of a decision reached in accordance with law and shall, except where compelling reasons of national security otherwise require, be allowed to submit the reasons against his expulsion and to have his case reviewed by, and be represented for the purpose before, the competent authority or a person or persons especially designated by the competent authority.

However, the obligation of protection towards undocumented migrants may be constructed under the more general ICCPR safeguards of the rights to non-discrimination (article 2), liberty and security of the person (article 9), due process of law (article 14) and equality before the law (article 26), understood as universal human rights and, in terms of the Covenant, applicable to all persons in the territory or under the jurisdiction of the State Party (article 2.1).

On the side of States, some of the concerns that are raised when the human rights of undocumented migrants are brought up are that they could restrict sovereign powers on immigration or endanger the economic stability and wellbeing of the national population. It has been argued that the human rights framework itself may offer an adequate balancing mechanism to allow for the exercise of State faculties, while at the same time promoting a coherent standard of respect and protection of fundamental human entitlements, central to constitutional democracies - many of which are receiving countries for migration. This 'human rights-sovereignty compromise' may shed light on ways of confronting the dilemma that anti-irregular immigration measures undoubtedly represent the idea of universal personhood and human dignity. ${ }^{15}$

In this respect, based on the legal framework, which has just been described, it must be reaffirmed that in speaking of the rights of migrants, the point of departure in the debate is not - as is often supposed - the national sovereignty of States and their ability to regulate territorial borders, but rather what the law, or different legal systems, have to say about such rights and the principles on which they are based. Indeed, the UN Special Rapporteur on the Human Rights of Migrants, François Crépeau, has highlighted the tendency observed in some declarations by public officials and the mass media to consider migrants who arrive in States and have not been invited to come, or to enter, as somehow not enjoying the same rights as other people. Such a pattern has led to the

\footnotetext{
15 See CM Rodríguez and R Rubio-Marin, The Constitutional Status of Irregular Migrants: Testing the Boundaries of Human Rights Protection in Spain and the United States' in MB Dembour and T Kelly (eds), Are Human Rights for Migrants? Critical Reflections on the Status of Irregular Migrants in Europe and the United States (Routledge 2011).
} 
creation of spaces of administrative discretion based on the underlying belief that there exist two kinds of human rights - those held by citizens, and those of a second-class category, held by non-citizens. It must be underlined though, as UN Special Rapporteur Crépeau has clarified, that international law is firm in laying down the standard that all human rights are to be enjoyed by all human beings, the only exceptions being those that are allowed by international human rights law itself. ${ }^{16}$ Public international law has been constructed, among other factors, precisely through the progressive understanding of State sovereignty as involving the responsibility of ensuring a series of values and living conditions for persons under the jurisdiction of States, qua persons with dignity, as a sufficient reason for the legal recognition and enjoyment of a set of rights. ${ }^{17}$ In that sense, the first assertion that needs signalling is that universal human rights are, in principle, applicable to all migrants, whether regular or irregular.

As Morten Kjaerum, Director of the EU Fundamental Rights Agency, recently emphasised, 'You do not need a visa or a residence permit to qualify for human rights. Simply being born is your passport to human rights protection'. ${ }^{18}$

\subsubsection{The European System}

Let us now take a brief look at some of the aspects that are worth highlighting in terms of the protection of universal human rights of undocumented migrants, particularly women, in the European context.

\footnotetext{
16 Statements by F Crépeau at the debate on The Management of the External Borders of the EU and Its Impact on the Human Rights of Migrants: The Italian Experience. A Consultation between the UN Special Rapporteur on the Human Rights of Migrants, Mr François Crépeau, Civil Society, and Academia', organised by the Migration Policy Centre, Robert Schuman Centre for Advanced Studies of the European University Institute (EUI), with the support of the Open Society Foundations, and held at the EUI in Florence (Italy, 3 October 2012); details on file with the author. The event was held within the context of the Special Rapporteur's mission to Italy, as part of his year-long study of the human rights of migrants at the borders of the European Union. Drawing on his experiences of similar visits, he developed a thematic study which was presented to the Human Rights Council in June 2013. The study analysed EU migration management in the context of border management, not only in light of the programmes and policies of the individual States visited but also considering the overarching EU migration policy framework, which focuses on its impact on the human rights of migrants. See press release, 'UN Special Rapporteur on the human rights of migrants concludes his third country visit in his regional study on the human rights of migrants at the borders of the European Union: Italy' Rome (8 October 2012) <www.ohchr. org/EN/NewsEvents /Pages / DisplayNews.aspx?NewsID=12640\&LangID=E $>$ accessed 15 October 2012 .

17 In this sense, see A Cassese, International Law (2nd edn, OUP 2005) 45.

18 M Kjaerum, 'Dignity and Rights of Irregular Migrants' (speech delivered at the $4^{\text {th }}$ Fundamental Rights Conference, Warsaw, Poland, 21-22 November 2011) 2 (emphasis in the original) <http://fra.europa.eu/fraWebsite/attachments/MK-Speech-FRC-NOV2011.pdf> accessed 2 December 2016.
} 
At the normative level, the 1950 European Convention on the Protection of Human Rights and Fundamental Freedoms (ECHR), while not referring specifically to migrants, protects them insofar as this is applicable to all persons under a State's jurisdiction. ${ }^{19}$ The 1961 European Social Charter (ESC) and the 1996 Revised European Social Charter (RESC) afford some degree of protection to undocumented migrants mainly through the right to non-discrimination in relation to different rights such as labour rights and guarantees of non-expulsion. ${ }^{20}$ Also, through the supervisory bodies of both instruments, the European Committee on Social Rights and the European Court of Human Rights (ECtHR) respectively, the rights of migrants have to a certain extent been reaffirmed and protected. However, the usual approach of the ECtHR has been to underline the obligation of States to ensure the right to family life (article 8) and to non-discrimination (article 14) with respect to other rights in relation to non-nationals who are lawfully residing in their territory, thus leaving undocumented migrants generally outside the protection of the system. However, in the realm of undocumented migrants, some interesting developments by European human rights bodies have taken place in recent years, as will be analysed below.

Regarding migrant women, the Council of Europe Convention on Preventing and Combating Violence against Women and Domestic Violence (Istanbul Convention) requires countries to ensure protection irrespective of (documented or undocumented) migrant status (article 4.3). The Convention, which entered into force in 2014, also singled out 'migrant women' as a group in a specific state of vulnerability, under the consideration that

migrant women, with or without documents, and women asylum-seekers are particularly vulnerable to gender-based violence. Although their reasons for leaving their country vary, as does their legal status, both groups are at increased risk of violence and face similar difficulties in overcoming it. It also requires that measures be taken to prevent such violence and support victims while taking into account the needs of vulnerable persons. ${ }^{21}$

\footnotetext{
19 European Convention on the Protection of Human Rights and Fundamental Freedoms (adopted 4 November 1950, entered into force 3 September 1953) CETS No 005, 213 UNTS 1932 (European Convention) art 1.

20 European Social Charter (adopted 18 October 1961, entered into force 26 February 1965) CETS No 035, 529 UNTS 89 (ESC); and European Social Charter (revised) RESC (adopted 3 May 1996, entered into force 1 July 1999) CETS No 163; see arts 18 and 19 of both instruments.

${ }^{21}$ See Istanbul Convention, 'Migrant Women, Women Asylum-seekers and Women Refugees' (emphasis added) <http://www.coe.int/en/web/istanbul-convention/the-convention-in-brief> accessed 3 December 2016.
} 
Addressing the conditions of undocumented migrants in Europe, let us recall that in its account of State obligations towards undocumented migrant domestic workers, especially women and children, the UN Committee on RMW qualifies the vulnerabilities they face as 'extreme' and based on article $69 \mathrm{CRMW}$ calls for States to take appropriate measures to address such vulnerabilities and 'consider policies, including regularization programmes, to avoid or resolve situations in which migrant domestic workers are undocumented or are at risk of falling into irregular status'. ${ }^{22}$ While it is true that EU countries are not party to the CRMW (although as noted above two Council of Europe countries are -Turkey and Albania), and as such they are not legally bound by its provisions, the authoritative force of the UN Convention as one of the core international human rights instruments should be considered in light of the values and principles sustaining Europe's human rights commitments.

While there are noteworthy normative advancements in Europe, when considering specifically undocumented migrant women, the response by the regional human rights system has been less categorical than at the UN level or in other regional scenarios. ${ }^{23}$

\subsection{Undocumented female migrants in Europe: workers and women at risk}

Concerning the condition of women migrant domestic workers, it has to be noted that the spectrum of discrimination, exploitation and human rights violations experienced by such workers is at times promoted by international law itself.

For instance, the recently adopted ILO Convention Concerning Decent Work for Domestic Workers of 2011, otherwise an important advance, excludes from the applicability of the Convention persons who perform domestic work only occasionally or sporadically and not on an occupational basis (article 1.c) and permits States parties to exclude wholly or partly from its scope 'limited categories of workers in respect of which special problems of a substantial nature arise' (article 2.2.b). ${ }^{24}$ In this context, recourse to private means to meet the demand for certain

\footnotetext{
22 UN Committee on the Protection of the Rights of all Migrant Workers and Members of Their Families, 'General Comment No 1: Migrant Domestic Workers' CRMW/C/GC/1, 23 February 2011, para 52.

23 Consider for example the broad protection by the Inter-American Court of Human Rights (IACHTR) in its Advisory Opinion, 'Juridical Condition and Rights of Undocumented Migrants', on the basis of equality and non-discrimination as ius cogens norms; IACHR, 'Juridical Condition and Rights of Undocumented Migrants' (Advisory Opinion OC-18/03 of 17 September 2003 requested by the United Mexican States (hereinafter AO 18-03)) para 101, and concluding paras 4, 6 and 8 .

24 ILO Convention 189, 'Convention Concerning Decent Work for Domestic Workers', adopted by the General Conference of the ILO at its 100th session, 16 June 2011.
} 
lines of work, and the recruitment of migrant domestic workers to meet 'care deficits', not only evidence a retreat from the welfare state, but also fail to pose broader questions on how to value and maintain care work.

In this context, the care deficit experienced in several European welfare states, especially in Southern Europe, is particularly relevant for migrant female workers. Indeed, the demand for domestic and other workers to carry out care functions often finds supply in migrant women. Although there is an identifiable demand-supply relationship, due to economic austerity and frequent fears for social and political cohesion running along (often post-colonial) ethnic and racial lines, the strains on a harsher State immigration policy have become stronger, shaping the construction of a 'transnational political economy of care'. ${ }^{25}$ As a result, European State policy has recently overlooked or denied the existence of such an economic relationship, closing the legal channels for safe migration routes to access the territory of demanding States and the care labour market, and thus prompting the entrance of migrants, especially women, through irregular means to the host State and creating spaces for them to live and work in an undocumented manner. ${ }^{26}$

This 'legal limbo' in turn places migrant women in an exposed position to labour exploitation, abuse and violence, with the differentiated gender dimension this involves. Like many of the rest of the so-called 'low-skilled' migrants, as well as the broad category of undocumented migrants, most women leave a State where they experience poverty and exclusion to move within a market that wants and needs migrants, but does not welcome them, in turn facing a State that offers few avenues to defend, protect and guarantee their rights. Indeed, human insecurity is the cause and consequence of their condition. Within the realm of migrants in general, though, the vulnerability constructed by the law is at the heart of undocumented migrant women's human insecurity.

Several civil society organisations have also documented the effects of the lack of access to justice of undocumented women abused and living in EU countries. ${ }^{27}$ For example, a recent Human Rights Watch report

\footnotetext{
25 See Fiona Williams, 'Towards a Transnational Analysis of the Political Economy of Care' (2011) SULCIS Working Papers, Stockholm University Linnaeus Center for Integration Studies - SULCIS / Scandinavian Working Papers on Economics, WP No 2011:6.

26 Summary presented by Siobhán Mullaly as part of a research project on Migrant Domestic Workers and EU Law, within the 'Workshop on Gender and Migration' held at the EUI on June 19-21 2012. Personal notes taken. See also UN OHCHR, Europe Regional Office, 'Rights of Migrant Domestic Workers in Europe' 2011 <www.europe.ohchr.org/Documents / Publications/Study_Domestic_Migrant_webversion.pdf> accessed 20 January 2013; and Anna Triandafyllidou, 'Irregular Migration and Domestic Work in Europe: Who Cares?' in Anna Triandafyllidou (ed), Irregular Migrant Domestic Workers in Europe: Who Cares? (Ashgate 2013) 1.

27 See Human Rights Watch (HRW), 'Belgium: Abused Migrant Women Fear Deportation. Legal Loopholes, Inadequate Shelter Access Send Women Back to Abusers' (New York, 8
} 
tellingly titled 'The Law Was Against Me: Migrant Women's Access to Protection for Family Violence in Belgium', found major protection gaps for migrant women who experience domestic violence in Belgium. Women who migrate to Belgium to join a husband or partner may face deportation if they report the violence during the period when their status is being confirmed, as do undocumented migrant women. Domestic violence victims, especially undocumented women, also lack adequate access to shelters. These shelters often require women to contribute to the cost. Undocumented women who cannot do so are not eligible for the financial support from local authorities available to other victims of domestic violence. Some women end up living on the streets after escaping very violent partners, who on occasions have threatened to kill them. ${ }^{28}$

Indeed, undocumented women are particularly vulnerable. Unauthorised stay in several EU countries is a criminal offence and police are required to report anyone who they suspect is in the country illegally to immigration authorities, such as in Belgium, for example. Women who do come forward have few avenues to obtain legal status, especially if they do not have children. Other women endure years of abuse at the hands of their partner, coming forward only when they obtain permanent residence through their children: only when they 'have papers'. ${ }^{29}$ One of the civil society logos of 'sans papiers, mais pas sans droits' ${ }^{\prime 30}$ seems crudely to come to mind.

Undocumented migrant women, including those who lost residency rights as a result of escaping violence, may risk deportation when they seek help from the police, and, even if they are entitled to receive protection, many do not know this and continue to fear deportation. Indeed, the real or perceived risk of deportation may create almost insurmountable barriers for undocumented victims of domestic violence to seek help and protection and can expose them to further abuse and exploitation. It also leads to impunity for perpetrators'. ${ }^{31}$

The way legal irregularity interacts with the susceptibility of women migrant workers, as exposed in the analysed sources, allows for a deeper

\footnotetext{
November 2012) <www.hrw.org/news/2012/11/08/belgium-abused-migrant-women-feardeportation> accessed 20 January 2013.

${ }^{28}$ See HRW, “The Law Was Against Me": Migrant Women's Access to Protection for Family Violence in Belgium' (New York, 8 November 2012).

29 ibid, Executive Summary. See also the web documentary by PICUM for accounts on immigration legislation in several European countries <www.undocumentary.org> accessed 20 January 2016.

30 See Groupe d' Information et de Soutien des Immigrés (GISTI), 'Les notes pratiques. Sans-papiers mais pas sans droits' (5e édition, juin 2009) <www.gisti.org/publication_pres. php?id_article $=1615>$ accessed 3 December 2016.

31 'The Law was Against Me' (n 28) 39.
} 
understanding of the 'constructed vulnerability' of these women. ${ }^{32}$ When confronted with the violation of a particular human right, undocumented migrants, and especially women and girls within this group, are unable or unwilling to turn to the institutional mechanisms in seeking redress for such violation. Due to the clandestinity derived from their irregular legal status, they fear denial of their rights or deportation if they dare come forward, or they often face serious substantive or procedural obstacles when they do. This violation of both a certain human right and of their right of access to justice translates into a double victimisation and constitutes a grave source of human insecurity, as will be detailed below.

\section{Responses by human rights actors in the UN and European contexts}

\subsection{UN human rights bodies}

The UN Committee on the Protection of the Rights of All Migrant Workers and Members of their Families (UN Committee on RMW), the body supervising compliance with the CRMW, plays a fundamental role in shedding light on the vulnerabilities faced by migrants, particularly female migrants, and clarifying the specific ways in which the human rights of all migrant workers, documented and undocumented, and members of their families should be understood and applied.

Indeed, the UN Committee on RMW noted that:

migrant domestic workers are at heightened risk of certain forms of exploitation and abuse...These risks and vulnerabilities are further aggravated for migrant domestic workers who are nondocumented or in an irregular situation, not least because they often risk deportation if they contact State authorities to seek protection from an abusive employer. ${ }^{33}$

In this sense, undocumented migrants often face double victimisation given that, on the one hand, their irregular status places them at a higher risk of violations of their human rights, and, on the other, their human right of access to justice is also affected because of their fear of deportation. The Committee also highlights a similar exposure and a correlated fear which aggravate such risk, when it analyses 'women mi-

32 On the role of the State in constructing vulnerability, see Bridget Anderson, 'Mobilizing Migrants, Making Citizens: Migrant Domestic Workers as Political Agents' (2010) 33 Ethnic and Racial Studies 1, 69. See also Francesca Scrinzi, 'The Globalisation of Domestic Work: Women Migrants and Neodomesticity' in Jane Freedman (ed), Gender and Insecurity: Migrant Women in Europe (Ashgate 2003).

33 General Comment No 1 (n 22) para 7 (emphasis added). 
grant domestic workers with irregular status, who are especially vulnerable during pregnancy, as they are often afraid to contact public health services out of fear of deportation' ${ }^{34}$ Similarly, the CEDAW Committee recently recognised in 2015 how migrant women are also disproportionately criminalised owing to their status, and the impact of this as an obstacle to their right of access to justice. ${ }^{35}$

Addressing the conditions of undocumented migrants at the global level, in its account of State obligations towards undocumented migrant domestic workers, especially women and children, the UN Committee qualifies the vulnerabilities they face as 'extreme' and, based on article 69 of the International Convention on the Protection of the Rights of All Migrant Workers and Members of their Families (CRMW), calls for States to take appropriate measures to address such vulnerabilities and 'consider policies, including regularization programmes, to avoid or resolve situations in which migrant domestic workers are undocumented or are at risk of falling into irregular status'. ${ }^{36}$

The intersectional discrimination ${ }^{37}$ suffered as an undocumented migrant worker and as a woman was also signalled by the UN CEDAW Committee in its General Recommendation No 26 on 'Women Migrant Workers' of $2008 .{ }^{38}$

Similarly, the ILO Convention Concerning Decent Work for Domestic Workers refers in articles 8 and 15 to the State obligation to also apply the provisions of the Convention to domestic migrant workers and the duty to protect them from abusive practices, including those carried out by private employers. ${ }^{39}$

Because of the pervasive risks detected in relation to the rights of undocumented migrants and the recognition that 'migrant workers and members of their families in an irregular situation often live in fear', the UN Committee on RMW dedicated its General Comment No 2 of 2013 to the broad questions regarding precisely '[t]he rights of migrant workers

\footnotetext{
34 ibid, para 43.

35 CEDAW Committee, 'General Recommendation No 33: Women's Access to Justice' CEDAW/C/GC/33, 3 August 2015, para 49.

36 General Comment No 1 (n 22) para 52.

37 On intersectional discrimination, see Kimberley Crenshaw, 'Mapping the Margins: Intersectionality, Identity Politics, and Violence Against Women of Color' (1991) 43 Stanford Law Review. See also Hope Lewis, 'Between Irua and "Female Genital Mutilation": Feminist Human Rights Discourse and the Cultural Divide’ (1995) 8 Harvard Human Rights Journal 1; and Taunya Lovell Banks, 'Toward a Global Critical Feminist Vision: Domestic Work and the Nanny Tax Debate' (1999) 3 Journal of Gender Race \& Justice 1, 1.

38 UN CEDAW Committee, 'General Recommendation No 26: Women Migrant Workers', CEDAW/C/2009/WP.1/R, adopted on 5 December 2008, para 2.

39 ILO Convention 189, Convention Concerning Decent Work For Domestic Workers, adopted by the General Conference of the International Labour Organization at its 100th session, 16 June 2011.
} 
in an irregular situation and members of their families'. Migrant women and girls within this group are unable or unwilling to turn to institutional mechanisms to seek redress for such violations. Due to the clandestine nature of their existence as undocumented workers, they fear denial of their rights or deportation if they dare come forward, for they often face serious substantive or procedural obstacles when they do. ${ }^{40}$

The increased risk of suffering human rights violations by female undocumented migrants has also been highlighted by the UN Special Rapporteur on Violence against Women, who stressed the particular vulnerability of undocumented immigrant women to violence, including sexual harassment and abuse, in the workplace. In the face of this 'red alarm', that is, knowing of the existence of actual abuses and risks of further violations, the State's obligations of protection are triggered. States have an obligation to prevent and protect immigrant women, as particularly vulnerable, from the human rights violations they have already suffered or are likely to encounter. ${ }^{41}$

Although not explicitly referring to undocumented migrant women, General Comment No 3 of the UN Committee Against Torture of 2012 seems to perfectly fit the conditions faced by such women and the need for States to guarantee their human rights and security in relation to their right of access to justice. The General Comment devotes significant attention to the duty for States to ensure that women and also victims of torture or inhuman or degrading treatment who are members of other marginalised or vulnerable groups (a category applicable to undocumented migrants, for example) are not denied access to justice or mechanisms for seeking and obtaining redress on a discriminatory basis, and also stresses that States must ensure that procedures to determine redress do not pose obstacles to members of vulnerable groups that could prevent or discourage them from pursuing their claims. ${ }^{42}$

The UN Human Rights Committee (HRC), the supervisory body reviewing compliance with the ICCPR, has also pointed out that once the migrant person is inside the territory of a country, for example retained within an administrative hostel, he or she deserves protection of the right to liberty and security of the person, especially if the individual is asking for refugee status and may be put at risk by returning to the country of origin. ${ }^{43}$

\footnotetext{
40 UN Committee on RMW, 'General Comment No 2: The Rights of Migrant Workers in an Irregular Situation and Members of their Families, 23 August 2013, point I.2.

41 Report of the UN Special Rapporteur on Violence against Women, Rashida Manjoo, UN General Assembly Resolution A/66/215, 2011, paras 43-46 (emphasis added).

42 UN Committee Against Torture, 'General Comment No 3: Implementation of Article 14 by States Parties' paras 32-34 (emphasis added).

43 See UN HRC, A v Australia, Communication No 560/1993, CCPR/C/59/D/560/1993, 3 April 1997, paras. 9.2 and 9.4 in relation to 7.2. See also the general evaluations by the
} 
In 2014, the UN HRC in its 'General Comment No 35: Article 9 (liberty and security of person)' clarified that the scope of the right of security of person under the ICCPR did not cover all risks to physical or mental health. However, related to the conditions faced by undocumented migrants and asylum seekers, the HRC did signal that '[d]ecisions regarding the detention of migrants must also take into account the effect of the detention on their physical or mental health', opening the door for challenging, among other State actions, prolonged detention, the precarious and unsanitary conditions of migration detention centres, the lack of judicial review of immigration and asylum procedures, and the deprivation of liberty of children, particularly considering the extreme vulnerability and need for care of unaccompanied minors. ${ }^{44}$

\subsection{European human rights bodies}

As mentioned above, the supervisory bodies of both the ECHR and the European Social Charter - the European Court of Human Rights and the European Committee on Social Rights, respectively - have reaffirmed the rights of migrants to a certain extent. However, again, the usual approach of the ECtHR has been to underline the obligation of States to ensure the right to private and family life (article 8) and to non-discrimination (article 14) with respect to other rights in relation to non-nationals who are lawfully residing in their territory. ${ }^{45}$

There are some important exceptions, though, to the general stand of only considering lawfully residing migrants in European human rights protection. The European Committee on Social Rights (ECSR), in monitoring Luxembourg's compliance, has interpreted article 13(4) of the European Social Charter as requiring Member States to ensure that all migrant workers, independently of their migration status, are able to access emergency social assistance for as long as they might require it, ${ }^{46}$ an obligation that was also reaffirmed by the Committee on RMW, as described above.

Let us recall, though, that the European Social Charter was adopted in 1961 with a nationality-based reciprocity structure as a foundational feature, and not with the primary aspiration of constituting an instru-

\footnotetext{
Working Group on Arbitrary Detention: Deliberation No 5 concerning the situation regarding immigrants and asylum-seekers, E/CN.4/2000/4, 2000; Situation regarding immigrants and asylum seekers, E/CN.4/1999/63, 1999; and Situations regarding immigrants and asylum seekers, E/CN.4/1998/44, 1998.

44 UN HRC, 'General Comment No 35: Article 9 (liberty and security of person)' CCPR/C/ GC/35, 16 December 2014, paras 9 and 18 .

45 See, eg, cases Gaygusuz $v$ Austria App no 173/71/90 (ECtHR 19 September 1996); and Poirrez $v$ France App no 40892/98 (ECtHR 30 September 2003).

46 See ECSR, Conclusions XIX-2 (Luxembourg) 22 December 2009.
} 
ment embodying universal human rights. In this respect, the interpretations by the ECSR may respond at least partly to the logic of guaranteeing the functioning of a system of mutual benefits, exchanges and tradeoffs and not necessarily or as a priority goal in upholding human rights standards. The ECSR has evolved, though, and has moved towards a less instrumental and a more protective interpretation with general significance for human rights law, such as that referred to above in reviewing Luxembourg's compliance, and explicitly addressing undocumented migrants. ${ }^{47}$

To give but another example of hopeful avenues to more protective positions, reciprocity arguments requiring the conditionality of analogous benefits in place in a first State party to legitimate compliance with the recognition of rights in a second State party have been rejected by dissenting members of the ECSR itself, reflecting that the importance of the Charter lies in its multilateral nature, with no reciprocity condition. If this principle is breached, its articles concerned with social protection might just as well be repealed'. ${ }^{48}$ Specifically regarding children of migrant workers addressed in the revision of the compliance of the UK, one of the dissenting members expressed concern over the majority's interpretation that 'States cannot be required to pay child allowances to nationals of States party when there is no corresponding entitlement', and added that this view was 'incompatible with the principle that equal treatment cannot be made subject to exceptions or reciprocity conditions'. Further preoccupation was expressed for considering that the majority interpretation disregarded cases 'where dependent children of migrant workers do not live on their territory or have a minimum period of residence or employment requirement which places non-nationals at a disadvantage'. ${ }^{49}$ And in reviewing the compliance of the Russian Federation with equal treatment of non-nationals regarding the right to vocational guidance and to vocational training accorded by the Charter (articles 9 and 10), the ECSR unanimously affirmed that 'length of residence requirements or employment requirements and/or the application of the reciprocity clause are contrary to the provisions of the Charter' ${ }^{50}$ It must

\footnotetext{
47 For an analysis of the ECSR, see Urfan Khaliq and Robin Churchill, 'The European Committee of Social Rights' in Malcolm Langford (ed), Social Rights Jurisprudence. Emerging Trends in International and Comparative Law (CUP 2008).

48 ECSR, Conclusions XVIII-1 (United Kingdom) arts 1, 5, 6, 12, 13, 16 and 19 of the Charter, 2006; Dissenting opinion of Mr Jean-Michel Belorgey, joined by Mr Nikitas Aliprantis, Mrs Csilla Kollonay-Lehoczky and Mr Lucien Francois; on first page of the opinion (emphasis added).

49 ECSR, Conclusions XVIII-1 (United Kingdom) arts 1, 5, 6, 12, 13, 16 and 19 of the Charter, 2006; Dissenting opinion of Mr Tekin Akillioğlu with Conclusion relating to Article 12, para 4; see last two paragraphs of the opinion.

50 ECSR, Conclusions 2012 (Russian Federation) arts 1, 9, 10, 15, 18, 20 and 24 of the Revised Charter, January 2013, 12-13 (emphasis added).
} 
be remembered, though, that most of these developments refer to documented non-nationals.

In this context, it is important to keep in mind that even if many migrant workers in an undocumented situation do not participate in contributory schemes of social security, they contribute to financing social protection arrangements and programmes by paying indirect taxes. ${ }^{51}$

Cases of alleged human rights violations deriving from the expulsion of non-citizens, and particularly of undocumented migrants, as well as the rules applicable to such expulsions, have usually been reviewed by the European Court in terms of violations of the non-refoulement principle under articles 3 (prohibition of torture), or under article 2 (right to life), on the one hand, or in the framework of violations of the right to private and family life on the other, but not in more general terms of respect of the right to due process of law and a fair trial. This can possibly also be explained in light of the fact that the ECHR does not include a mirror provision to that of article 13 ICCPR described above (rights of aliens to legal certainty, due process and a fair trial when confronting an expulsion decision). The lack of such a provision has left the Court with its hands somewhat tied, given it confronts obstacles to review generalised situations of risk and actual violations faced by undocumented migrants in the host State; and when they reach the limit of an order of expulsion against them or of actually having been expelled, the Court can only verify if a few minimums were observed.

In terms of jurisprudential responses, as noted, the ECtHR has traditionally reviewed cases of documented migrants. ${ }^{52}$ A few interesting cases have involved undocumented migrants, although those already falling under the legal category of 'asylum seekers' and not solely as 'undocumented migrants'. ${ }^{53}$ In terms of the gendered dimension of the ECtHR's case law, particularly noteworthy are the cases considering undocumented migrants suffering from HIV/AIDS and confronting probable

\footnotetext{
51 See Report of the United Nations High Commissioner for Human Rights to the Economic and Social Council' E/2010/89, 1 June 2010, para 46.

52 Think, eg, of Gaygusuz $v$ Austria and Poirrez $v$ France (n 45), as well as the more recent case of $B S v$ Spain concerning a documented migrant woman from Nigeria working as a prostitute in Mallorca and treated in a discriminatory manner by police officials, as sustained by the ECtHR which concluded on the State responsibility of Spain: BS $v$ Spain App no 47159/08 (ECtHR 24 July 2012).

53 See, eg, MSS $v$ Belgium and Greece App no 30696/09 (ECtHR 21 January 2011) protecting a male Afghan asylum-seeker; Nacic and Others $v$ Sweden App no 16567/10 (ECtHR 24 September 2012) involving a Roma family seeking asylum; and AA $v$ Sweden App no 14499/09 (ECtHR 28 September 2012) regarding asylum-seeking women from Yemen, in both cases denied protection by the ECtHR. In relation to MSS $v$ Belgium and Greece, see also the case of the Court of Justice of the European Union (CJEU) in NS and Others $v$ SSHD, Judgment of the Court (Grand Chamber), 21 December 2011, in Joined Cases C-411/10 and C-493/10.
} 
poor healthcare conditions upon return to their country of origin as a result of deportation. The ECtHR has analysed these situations from the perspective of risk of torture or ill-treatment and, as such, as a possible violation to the non-refoulement obligation of article 3 ECHR. However, as will be analysed below, while in $D v U K,{ }^{54}$ a case of 1997 concerning an HIV-positive undocumented migrant man from Saint Kitts and Nevis residing in the UK, the ECtHR adopted a protective stance which ultimately allowed him to stay in the UK, in $N v U K^{55}$ of 2008, involving an undocumented woman from Uganda in a similar situation, the Court denied such protection.

Indeed, concerning this last case, the woman, $\mathrm{N}$, had received lifesustaining medical treatment that would purportedly allow her to live 'for decades'. $\mathrm{N}$ had been rejected as an asylum seeker and if she were to be deported back to Uganda, there was strong evidence that due to the lack of anti-retroviral drugs for her in the Ugandan health system she would die within two years of her return. The Court concluded that the removal of $\mathrm{N}$ to Uganda would not entail a violation of the non-refoulement obligation contained in article 3 ECHR prohibiting the removal of a person in the case of a risk of torture or cruel, inhuman or degrading treatment. ${ }^{56}$

Some of the criticisms against this sentence have been countered rather dismissively:

Disappointing to many as this case may seem, it is in line with earlier case law to a great extent. In fact, the Court has held only once in a health case context, in a case of an applicant with HIV/ AIDS who would be sent back to the tiny island of St Kitts ( $D v$ the United Kingdom), that Article 3 would be violated if the applicant would be expulsed. ${ }^{57}$

However, the joint dissenting opinion of Judges Tulkens, Bonello and Spielmann in the case of $N v U K$ expressed concern with the Court taking a stand in this case different from that in the analogous judgment of $D v$ United Kingdom, mentioned above, issued more than 10 years before.

\footnotetext{
$54 \quad D v$ United Kingdom App no 30240/96 (ECtHR 2 May 1997).

55 Nv United Kingdom App no 26565/05 (ECtHR 27 May 2008).

56 See the analysis of the $N v U K$ case in Daphne Barak-Erez and Aeyal M Gross (eds), Exploring Social Rights: Between Theory and Practice (Hart Publishing 2007) 192; and in Malcolm Langford, Social Rights Jurisprudence (CUP 2008) 288.

57 'Grand Chamber Judgment in $N v$ UK' (ECHR Blog, Wednesday 28 May 2008) <http:// echrblog.blogspot.com.es/2008/05/grand-chamber-judgment-in-n-v-uk_28.html> accessed 20 January 2013. For a more detailed overview of the Court's case law on the issue of expulsions of persons with health problems under article 3 ECHR, see Derckx Veelke, 'Expulsion of Illegal Residents (Aliens) with Medical Problems and Article 3 of the European Convention of Human Rights' (2006) 13 European Journal of Health Law 313.
} 
In that case involving an applicant with HIV/AIDS who would be sent back to St Kitts where he would be left deprived of healthcare and moral support, the Court declared that article 3 would be violated if he was expulsed, given that he was at a 'critical stage' of illness. ${ }^{58}$ The dissenting judges argued that the case of $N v U K$ - in which the applicant 'with no doubt' would face 'an early death' on return to Uganda - was no different in its extreme circumstances to $D v U K$. They concluded that

finding a potential violation of Article 3 in this case would not have been an extension of the exceptional category of cases which is represented by $D v$ the United Kingdom... The distinguishing of the present case from that of $D v$ the United Kingdom is thus, in our opinion, misconceived. ${ }^{59}$

They also emphasised their grave concern with the Court's balancing exercise when dealing with article 3 , a non-derogable right containing a prohibition of an absolute nature and, thus, not subject to 'a fair balance between the demands of the general interest of the community and the requirements of the protection of the individual's fundamental rights', as the Court had carried out with respect to N's case, ${ }^{60}$ a balancing that the same Court had actually explicitly prohibited three months before in Saadiv Italy.

In analysing the validity of returning very ill persons to countries with poor healthcare facilities under a gendered human rights lens that highlights the transnational dimensions of the issue, several reflections may be spelled out. As Eva Brems puts it, this type of case

reveals an uncomfortable truth about the limits of the human rights commitment of European states. Like other rich states with long democratic traditions, they like to insist on the universality of human rights vis-à-vis less democratic (and often poorer) other states. Yet in transnational situations, their formal commitment to universal human rights is upheld only thanks to barely credible legal wriggling ... [and] a legal reasoning that allows them to wash their hands in innocence. The dissenters brilliantly pierce through this legal fiction. ${ }^{61}$

\footnotetext{
58 D $v$ the United Kingdom App no 30240/96 (ECtHR 2 May 1997).

$59 \quad N v$ United Kingdom (n 55) Joint Dissenting Opinion of Judges Tulkens, Bonello and Spielmann paras 23 and 24.

60 ibid, para 7. See also para 44 of the judgment. See also a comparative examination of the two cases in this sense in Catherine Dauvergne, Making People Illegal: What Globalization Means for Migration and Law (CUP 2008).

61 Eva Brems, 'Thank You, Justice Tulkens: A Comment on the Dissent in N v UK' (The Strasbourg Observers, 14 August 2012) <http://strasbourgobservers.com/2012/08/14/thankyou-justice-tulkens-a-comment-on-the-dissent-in-n-v-uk/> accessed 20 January 2013.
} 
Indeed, the dissenting judges brilliantly uncovered the real fear of the majority when they clarified that the claim had not been articulated that article 3 places 'an obligation on the Contracting State to alleviate ... disparities through the provision of free and unlimited health care to all aliens without a right to stay within its jurisdiction', as the majority had affirmed. The judges highlight that

the view expressed by the majority that such a finding 'would place too great a burden on the Contracting States'...reflects the real concern that they had in mind: if the applicant were allowed to remain in the United Kingdom to benefit from the care that her survival requires, then the resources of the State would be overstretched.

They firmly rebut by emphasising that such a consideration

runs counter to the absolute nature of Article 3... and the very nature of the rights guaranteed by the Convention that would be completely negated if their enjoyment were to be restricted on the basis of policy considerations such as budgetary constraints.

In addition, they also reaffirm the absolute nature of the protective status of article 3 when countering the underlying belief of the majority that the implicit acceptance... of the allegation that finding a breach of Article 3 in the present case would open up the floodgates to medical immigration and make Europe vulnerable to becoming the "sick-bay" of the world'. In adopting an evidence-based approach, the dissenting judges underline that "the so-called "floodgate" argument is totally misconceived'. ${ }^{62}$

Considering the particular condition of vulnerability in place in this case, it must also be noted that $\mathrm{N}$ had escaped Uganda on account of having been ill-treated and raped. ${ }^{63}$ Under a gendered lens, the ECtHR overlooked the differentiated impact of HIV and its manifestations for women specifically within a context of discrimination and violence against women. ${ }^{64}$

The more humanitarian jurisprudential line of $D v U K$ may possibly be recovered at some point. In the case of $S J v$ Belgium, concerning the threatened expulsion from Belgium of a Nigerian mother suffering from

${ }_{62} N v$ United Kingdom (n 55), Joint Dissenting Opinion of Judges Tulkens, Bonello and Spielmann, para 8.

${ }^{63} N v$ the United Kingdom (n 55) para 10.

${ }^{64}$ See Manisuli Ssenyonjo, 'Human Rights of Women in Africa: A Prerequisite for Human Security' in Ademola Abass (ed), Protecting Human Security in Africa (OUP 2010). See also Statement by the African Union Chairperson, Professor Alpha Oumar Konare, in Celebration of the International Women's Day of 8 March 2007. 
AIDS, the applicant alleged an article 3 violation in regards to being returned to Nigeria. In the end, the parties reached a friendly settlement in August 2014, which the State agreed to on the basis of the 'strong humanitarian considerations weighing in favour of regularising [the applicant's] residence status and that of her children'. On 6 January 2015, the applicant and her children were issued with residence permits granting them indefinite leave to remain. ${ }^{65}$ However, it could be noted that in this case the ECtHR failed to seize the chance to establish a clear and firm interpretation on the scope of State obligations concerning the rights of seriously ill migrants. ${ }^{66}$

\section{Some conclusions}

Being an undocumented migrant woman or girl constitutes one of the greatest sources of vulnerability in our world today. I argue that assuring the principle of universality of all human rights towards undocumented migrants and other non-citizens is one of the most challenging situations for contemporary public international law. In the case of female undocumented migrants, another legal and political principle is put to the test: gender equality as a human rights axiom and a commitment of democratic societies. Indeed, the right to equality is materialised in the case of undocumented migrant women in their right to be free from discrimination. Understanding violence against women as a form of discrimination against women, as reviewed above, allows us to reinforce migrant women's right to live free from violence. The values sustaining the human rights system oblige the State and other actors to prioritise the protection of such women and their right to live free from violence over irregular migratory status.

The empirical realities of constant risks, deportability and lack of access to justice faced by undocumented migrants and migrant domestic workers, coupled with existing legal gaps, including in international human rights and labour law, impact directly and disproportionately on irregular migrant women and girls, placing them in conditions of heightened vulnerability to different forms of violence, including sexual violence. It also exposes other forms of violence against migrant women and girls, such as those of an institutional or economic nature, and the intersectional forms of discrimination, deprivation and poverty experienced by

\footnotetext{
65 SJ v Belgium App 70055/10 (ECtHR, Friendly settlement, 26 August 2014). Grand Chamber decision of 19 March 2015 to strike the case out of the ECtHR's list.

66 In this line, see Sara Ganty, 'SJ v Belgium: Missed Opportunity to Fairly Protect Seriously Ill Migrants Facing Expulsion' (Strasbourg Observers Blog, 30 April 2015) <https: / /strasbourgobservers.com/2015/04/30/s-j-v-belgium-missed-opportunity-to-fairly-protect-seriously-ill-migrants-facing-expulsion/> accessed 3 December 2016.
} 
female undocumented migrants on account both of their gender and of their irregular migratory status.

Looking at the international legal framework, though, in a world in which we have now constructed a sufficiently solid legal architecture reaffirming the human rights of all persons mainly through State obligations, it would seem that the rights of migrant persons ought to be made operational according to certain criteria - physical proximity, residence, or efforts and degrees of social integration - but that in any case the question is more about the distribution of obligations than about the existence and applicability of such rights.

Still, assuring the human rights of undocumented migrants and other non-citizens has become one of the most challenging situations for contemporary international law. In theoretical terms, it tests the applicability of the principle of the universality of human rights to undocumented migrant persons: the cosmopolitan promise of international human rights law is put to trial. And in practical terms, it is a challenge as well because the condition of the undocumented migrant is one of the gravest sources of vulnerability today.

Migration across borders is an archetypical transnational phenomenon open to new frames of thought that transcend the traditional view of the State as the main actor entrusted with human rights protection within its jurisdiction. These perspectives are called for particularly in view of the detrimental effect on human rights of the increasingly severe application of immigration restrictions, which may and does leave persons outside the law or invisible to the law, ${ }^{67}$ and therefore in a situation of State-constructed vulnerability. Paradoxically, the strict and often arbitrary application of certain laws, in the form of administrative (and increasingly criminal) immigration regulations, seems to be hindering the effective implementation of human rights law, with respect to sizeable sectors of the population, namely undocumented migrants.

The irregular character of their entry or residence in a given State would seem to extend at times to the whole realm of the human experience of undocumented migrants, particularly women. In addition, the perceived threat posed by increased migration and population mobility, both within and across borders, is often presented as a critical situation where respect for human rights is seen as an additional luxury because undocumented migrants are considered to enjoy or deserve diminished human rights protection. These conditions tend to place undocumented

67 See for example Franck Düvell and Bastian Vollmer, 'European Security Challenges' (Background Paper, EU-US Immigration Systems 2011/07, European University Institute, 2011). 
migrants in a certain 'legal limbo', void of rights or the possibility of accessing them.

This article has argued that a view from the perspective of international human rights law to the situation of undocumented migrant women and girls in Europe is required as a complement to European human rights law, in order to allow for a joint construction of more just, egalitarian and efficient responses to the heightened vulnerability and discrimination they confront. This is an essential road to take if we are to truly uphold the human rights of all persons and the values that sustain them in the democratic societies of Europe today and in the decades to come. 